Article

\title{
Trust and Tolerance across the Middle East and North Africa: A Comparative Perspective on the Impact of the Arab Uprisings
}

\author{
Niels Spierings \\ Department of Sociology, Radboud Social Cultural Research, Radboud University, 6525 HP Nijmegen, The Netherlands; \\ E-Mail: n.spierings@maw.ru.nl
}

Submitted: 1 September 2016 | Accepted: 22 January 2017 | Published: 24 March 2017

\begin{abstract}
The protests that swept the Arab Middle East and North Africa (MENA) are expected to have influenced two key civic attitudes fundamental to well-functioning democracies: trust and tolerance. However, systematic comparative assessments of the general patterns and particularities in this region are rare. This contribution theorizes the uprisings' impact and presents new society-level measurements of trust and tolerance for the MENA, synchronizing over 40 Arab Barometer and World Values Survey surveys on Algeria, Egypt, Iraq, Jordan, Lebanon, Morocco, Palestine, Tunisia, and Yemen, from before and after the uprisings. The analyses firstly show political-institutional trust falling in the uprisings' aftermath in countries that went through democratic reform or regime change. It appears that politicians misbehaving and reforms not resolving social problems hurt people's trust in politics. Secondly, in democratic transition countries Egypt and Tunisia, a decrease in social trust reflected the pattern of political-institutional trust indicating a spill-over effect. Thirdly, ethnoreligious tolerance dropped region-wide after the uprisings, indicating that the aftermath of religious conflict impacted the entire Arab region. These results support rational-choice institutionalist theories, while at the same time refining them for the MENA context.
\end{abstract}

\section{Keywords}

Arab spring; civic attitudes; democracy; Middle East; public opinion; tolerance; trust; uprisings

\section{Issue}

This article is part of a multidisciplinary issue of Politics and Governance, edited by Christian Haerpfer (University of Vienna, Austria) and Kseniya Kizilova (Institute for Comparative Survey Research, Austria).

(C) 2017 by the author; licensee Cogitatio (Lisbon, Portugal). This article is licensed under a Creative Commons Attribution 4.0 International License (CC BY).

\section{Introduction}

During the Arab uprisings, millions took to the streets. The public was fed up with corruption, poverty, unemployment, suppression, and inequality. Moreover, people did not trust institutional procedures and ruling politicians to solve these problems (e.g. Heydemann, 2013; Longley Alley, 2013; Robbins, 2015). While a lack of political trust was clearly at the root of these uprisings, we still know little about how the protests and their aftermath influenced people's civic attitudes, including political and social trust and tolerance. Yet these civic attitudes are crucial in establishing a sustainable democratic system in which people accept the outcomes of the political process and realize that they can hold their government accountable through elections (e.g. Fish, 2002;
Geddes, 2007; Gibson, 2009; Inglehart, 1997; Norris, 2011). It thus is important to ask how the Arab uprisings affected political-institutional trust, interpersonal trust, and ethno-religious tolerance across the Middle East and North Africa (MENA).

Some MENA case studies suggest that both the protests and the subsequent lack of clear change toward democracy or reduction in economic hardship impaired public opinion considerably. For instance, as Heydemann (2013, p. 59) writes on Syria, "the democratic aspirations of the protesters who filled streets and public squares...were among the conflict's first casualties". And on the failed transition in Egypt, Brown (2013, p. 53) states that by discrediting democratic promises all that remained was "a cloud of distrust and suspicion". Still, any systematic theorization or empirical assessment of 
how trust and tolerance have developed under the uprisings is lacking.

Though the more Western oriented literature on civic attitudes provides an important background to understanding the uprisings' impact, it cannot provide readymade answers. While it shows that trust and tolerance are relatively stable, driven by slow endogenous processes and shaped by institutional contexts (cf. Mishler \& Rose, 2001; Van der Meer \& Dekker, 2011; Zmerli \& Hooghe, 2011), the literature also acknowledges that these civic attitudes are subject to contextual shocks (e.g. political events) and that our knowledge on this is limited. So while we have learned from (empirically supported) rational-choice theories that a country's political and economic developments, such as economic performance, affect its citizens' attitudes (Easton, 1975; Gibson, 2009; Hutchison \& Gibler, 2007; Rose \& Mishler, 2011), and we know from sociological and classic institutionalism that religio-cultural differences, economic processes, and political institutional arrangements socialize generations in certain base levels of trust and tolerance (Growiec \& Growiec, 2014; Inglehart, 1997; Lühiste, 2006), it is less clear how and under which conditions shocks, like the uprisings, actually influence trust and tolerance.

By combining these existing insights with specific observations from case studies and unique comparative empirical MENA material on the recent events, this study will (a) provide new empirical insights into both the impact of the Arab uprisings, and whether and how this impact differs across the region; (b) empirically assess the applicability of existing theories-which are mainly grounded in Western democracies and Central and Eastern Europe (CEE) - to the MENA region; (c) explore the conditions under which the uprisings are found to have had an impact, explaining differences across the region; and (d) consequently generate new empiricallygrounded theoretical insights on what drives changes in these supposedly stable civic attitudes of trust and tolerance, feeding back into existing theories.

Empirically, I present diachronic and synchronic comparisons of nine MENA countries and over forty surveys. These comparisons have become possible by the synchronization of Arab Barometer and World Value Survey (WVS) data in the PRiME project. ${ }^{1}$ The diachronic comparison will help lay bare longer-term developments, which is crucial for establishing whether changes in attitude before and after the uprisings are not merely part of a larger trend such as generational replacement (cf. Robbins, 2015). The synchronic nine-country comparison then assesses the conditions (e.g. countries' institutions and the uprisings' form) under which the uprisings have influenced people's trust and tolerance.

\section{Theoretical Background}

There is a vast literature on political trust, interpersonal trust and tolerance. And before turning to the more spe- cific expectations of the uprisings' impact, I will provide a general background of the existing explanatory theories for the developments in these civic attitudes. As this study has set out to explain society-level developments in trust and tolerance and the differences between countries therein, macro-level explanations will be the focus here. Using this literature, I will then formulate specific expectations for these civic attitudes, which, although their general frames are similar, are thought to are explained by different specific factors (see e.g. Newton, 2001).

\subsection{Explaining Macro-Level Civic Attitudes}

A first important frame for understanding any development in civic attitudes over time is found in sociological institutional approaches, which mainly predict stability and slow changes. The economic and cultural situation both in a country and in intermediary societal groups are said to socialize generations into certain base levels of trust and tolerance, particularly at a young age (Easton, 1975; Gibson, 2009; Inglehart, 1999). In this vein, Growiec and Growiec (2014), for instance, argue that a way out of the low-trust trap in the transitional CEE countries is economic modernization. Logically, this approach sees generational replacement as an important driver of (slow gradual) change (see Gibson, 2009; Inglehart, 1997; Mishler \& Rose 2001; Zmerli \& Hooghe, 2011). Moreover, sociological institutionalism helps to explain differences between countries based on their different economic structures and cultural backgrounds, as for instance illustrated by Lühiste (2006) on the post-communist Baltic states, where political trust still suffers from the legacy of authoritarian communist rule.

Related to this approach is the classic institutionalist approach that focuses on the formal institutional context in which people live. This approach mainly helps to understand differences between countries. Stressed most in this respect is the difference between authoritarian and other regimes, the former's control over the people and its suppression of opposing ideas leading to low civic-attitude levels (Mishler \& Rose, 2001; Zmerli \& Hooghe, 2011). This phenomenon has also been linked to lasting effects after transitions to more open systems in the CEE (see Marinova, 2011; Murray, 2008). At the same time, as the transitions in the CEE have illustrated, regime types can change and this provides some explanations for changes in civic attitudes (Murray, 2008). Particularly, this approach puts forward that no short-term miracles should be expected from democratic transitions, as they lead to the breakdown of existing structures and the general disappearance of certainties. Consequently, already relatively low levels of civic attitudes cannot be expected to increase overnight or might even decrease (see Raiser, Rousso, \& Steves, 2004), nor will unpopular groups be liked all of a sudden (cf. Gibson, 2009).

To explain more rapid and short-term changes, the rational-choice-based frame provides most apt explana-

\footnotetext{
${ }^{1}$ Political and Religious attitudes and behavior in the Middle East.
} 
tions. This approach mainly focuses on people's recent experiences (Easton, 1975; Gibson, 2009). And although this seems to shift the focus to the micro level, it still is relevant to this study, as societal-level events shape people's subjective experiences (Hutchison \& Gibler, 2007; Rose \& Mishler, 2011), and because it has been shown that sociotropic perceptions can outweigh egocentric ones (Gibson, 2009, p. 418). More concretely, from this perspective we can deduce that for instance economic performance and religious cleavages at the societal level affect people's civic attitudes, and that these macro-level factors thus help explain different levels of trust and tolerance between societies and within societies over various years.

\subsection{Theorizing the Impact of Political Shocks in the MENA Region}

The institutional and rational-choice approaches discussed above provide important background knowledge for analyzing the Arab uprisings' impact on civic attitudes in the MENA. The first assumption that can be made is that society-level civic attitudes are expected to have already been relatively low before the uprising. Secondly, civic attitudes are expected to be relatively stable over the roughly 14 years studied here. Thirdly, both the classic institutionalist and the rational-choice frame suggest that major political events-revolution, war, terrorist attacks, and regime change-can have considerable impact, at least in the short and mid-to-long term.

At the same time, the relative idiosyncrasy of such events also ensures that any insights derived from the existing frames are difficult to generalize, as illustrated by the two relatively recent political shocks that have received attention in the literature: 9/11 and the democratic wave across CEE. Studies on $9 / 11$ show that, as a result of a new threat perception, political trust in the U.S. surged and tolerance decreased (e.g. Chanley, 2002; Davis \& Silver, 2004; Gross, Aday, \& Brewer, 2004; Skitka, Bauman, \& Mullen, 2004). However, studies on the transition to democracy in CEE suggest that uncertainty inhibits any increase in political-institutional trust in a newly less-authoritarian context, though the transition might actually strengthen trust in informal networks as compensation (see Growiec \& Growiec, 2014; Marinova, 2011; Murray, 2008; Raiser et al., 2004). These results suggest that political shocks have no single unequivocal effect; the impact of such events depends on the characteristics of the shock and context. So the first very general expectation in this study is that the impact of the uprisings differs considerably across countries and the different civic attitudes (Expectation 1).

Moreover, any systematic assessment of the uprisings' impact on civic attitudes in the MENA should thus dovetail the general frames discussed above with the country specificities and the institutional differences across the region. Below, I will therefore address the three civic attitudes focused on in this study-political-institutional trust, interpersonal trust and ethno- religious tolerance-one by one and address the claims made about these civic attitudes in the MENA country studies after the uprisings. By doing so from the perspective discussed above, I can formulate new, partly explorative, expectations on the uprisings' impact.

\subsection{Trust}

Generally, political and interpersonal trust correlate at the societal level. Some have argued that politicalinstitutional trust partly depends on people's more general interpersonal trust (e.g. Lühiste, 2006), while others argued that both have their own dynamics, at least at the individual level (e.g. Kaase, 1999; Newton, 2001). Unfortunately, claims about the Arab uprisings do not clearly distinguish between these two forms of trust. Yet to formulate clear expectations, this distinction is important.

Political-institutional trust, or political trust, in short, refers to people's acknowledgment of the government's authority and their willingness to accept the outcomes of the government's decision making as they believe politicians generally act fairly (Zmerli \& Hooghe, 2011, p. 3). Interpersonal or social trust, on the other hand, refers to the belief that other people are generally willing to behave in ways that are not detrimental to others, thus measuring the way people "evaluate the trustworthiness of the world they live in" (Benson \& Rochon, 2004; Newton, 2001, p. 203).

Political-institutional trust. Brown (2013) and Robbins (2015) link the failed transition in Egypt to a growing distrust of political authorities, but they neglect to explain why a drop in trust should be expected. Given Egypt's longstanding authoritarian history and malfunctioning government it is likely that political trust was already low or gradually declining, unless the regime change and free elections actually boosted trust at first. In this line, for Yemen, Longley Alley (2013, p. 89) talks about a strain due to economic hardship felt by millions of Yemeni, indicating trust was already low but did not drop in any major way. Or, as Boduszyński and Pickard formulate explicitly for Libya, "Libya's past-not only the years of the Qadhafi regime but also decades under brutal Italian colonial rule and then a corrupt monarchyhas made many Libyans deeply distrustful of all central authority" (2013, p. 89).

These accounts echo the literature on political trust in (transitioning) authoritarian regimes, but it does not become clear why a low but stable trust is (implicitly) expected in some cases while a decrease is noted in others. Combining these case insights with the general literature, however, leads me to formulate at least two concrete expectations. Firstly, only in the cases where political trust was relatively high can a drop be expected due to the introduced uncertainty (Expectation 2). Secondly, as a response to the uprisings some governments initiated some democratic reform (e.g. Morocco) or experienced a successful democratic transition (e.g. Tunisia). In those cases, a rational-choice institutional approach would sug- 
gest that (a) trust might have risen as political authorities became more responsive, but also that (b) this newfound trust was not a matter of long-term socialization and thus still fragile. Citizens who were disappointed by the actual economic and political results of the uprisings-for instance, politicians falling back into old authoritarian and sectarian political habits (e.g. Egypt) - can then be expected to lose their newly-found political trust, the latter even dropping below original levels, as the "good guys" also turn out to be similarly untrustworthy or hungry for power (Expectation 3).

Interpersonal trust. Boduszyński and Pickard's discussion of Libya (2013, p. 91) talks about a general "trust deficit", one particularly linked to intra-country cleavages. This is unlikely to be restricted to Libya, as the entire MENA shares a (neo-)colonial history in which ethnoreligious divides have become salient after the colonial powers drew their own borders. To illustrate, in 1915, British diplomat Mark Sykes, staring at a map, is recorded to have said: "I should like to draw a line from the ' $E$ ' in Acre to the last ' $K$ ' in Kirkuk" (Barr, 2011). Moreover, or consequently, many people in the MENA do not solely identify as Libyan, Moroccan, or Yemeni, but also as Arab citizens or part of the Umma, ${ }^{2}$ and many share a language, and thus media accounts of what happens in one country easily reach citizens of and in another country.

The observations in country studies suggest that the uprisings have harmed interpersonal trust. Looking more closely at the regional conditions and linking these to the experiences as focused on in the rational-choice approach, it can expected that in the countries that are ethnoreligiously diverse and where the protests were organized by particular ethnic or religious groups (e.g. Bahrain, Iraq, Lebanon), the violence and upheaval might have harmed trust in "people" in general (Expectation 4). Considering the Arab regional identity and the fact that interpersonal trust refers to "the world people live in" (see above) means that increased group tensions during the uprisings can also be expected to have harmed interpersonal trust across the region, albeit to a weaker degree (Expectation 5).

In addition, the above arguments on political trust might also apply to interpersonal trust, as, in several countries, people came to power who had not been considered part of the political elite before. Their actions might not only influence people's political trust, but also rub off on people's general views on the world's trustworthiness. Particularly in countries experiencing a democratic transition as well as untrustworthy and corrupt new leaders, we can thus also expect interpersonal trust to drop (Expectation 6).

\subsection{Tolerance}

In the Western political science literature, tolerance is generally defined as being prepared to extend civil rights to disliked societal groups (e.g. Communists, Muslims, feminists) (see Djupe \& Calfano, 2012; Scheepers, Gijsberts, \& Coenders, 2002). Possibly due to the general absence of guaranteed civil rights, the common conceptualization of tolerance in non-Western countries instead centers on the extent to which people from other backgrounds are welcomed in the community, particularly whether people object to having these "outsiders" as neighbors (e.g. Ciftci, 2010; Moaddel, 2006; Spierings, 2014). Both conceptualizations tap into the same conceptual focus: how people respond to others with different worldviews.

The rational-choice and sociological-institutionalist frames clearly direct this study's assessment of social or ethno-religious tolerance to perceived sociotropic threats. We can assume that the uprisings have spread and heightened the threat perception because of increased ethno-religious tensions, protests, and conflicts-or at least that these tensions have become more widely visible. Consequently, the uprisings are expected to have negatively impacted ethno-religious tolerance. Heydemann (2013, p. 65), for instance, talks about the Syrian events having "led to partial sectarian cleansing in rural areas, destroying longstanding patterns of intersectarian tolerance between Sunni and minority villages in conflict affected areas". This effect is expected in MENA societies with clear ethno-religious cleavages (Expectation 7), as well as across the region, since ethnoreligious tolerance is strongly connected to the shared (neo-)colonial history of, and identity discourse in, the MENA (Expectation 8).

\section{Data and Methods}

To assess the MENA region's developments in trust and tolerance and the differences between countries, I have synchronized over 40 existing public-opinion surveys to assess the impact of the uprisings on the civic attitudes. Moreover, I embedded these data in a country classification drawing from existing studies and media reports in order to assess how differences in the uprisings' impact relate to differences in the countries' protests and their aftermath.

Based on the surveys, aggregated macro-level descriptive statistics will be presented for 37 country-year combinations. Because this study does not focus on individual-level explanations of civic attitudes, macrolevel descriptive analyses are most suitable to assess both whether trends and changes are due to specific outliers, as well as what the general developments are. This approach combines the strengths of case knowledge and those of representative public-opinion data as it not only allows for systematic comparisons but also for a more exploratory assessment of the patterns, which might identify important factors not derived from the theories and

\footnotetext{
${ }^{2}$ The WVS includes questions on the degree to which people identify with their country and with the Arab nation. These figures show that in almost all country-years for which both are available, the identifications differ only slightly. Overall, on a scale from 0 (weakest) tot 3 (strongest), the means are 2.54 (nation) and 2.31 (Arab), indicating that people identify strongly with both.
} 
literature described above. In that sense, a visual descriptive analysis of a limited number of countries is rather demanding as regards the theoretical expectations, because each deviation needs to be considered and thus can severely undermine any theoretical claim. In some instances, additional statistical tests are used to establish whether changes in the society-level attitudes are likely to have been caused by chance-for instance if they are relatively modest or only found in a few countries-and these will be discussed in the text where relevant. ${ }^{3}$

\subsection{Surveys}

The statistical analyses in this study are based on Arab Barometer $(A B)$ and WVS data, three rounds each, which have been synchronized in the PRiME project. A core goal of this project is to create indicators for systematic comparative analysis even though different items are available across country-years. The exact procedures are discussed below. For eight countries at least one nationally representative survey ${ }^{4}$ from before 2011 and one from 2013 or 2014 were available: Algeria, Egypt, Iraq, Jordan, Lebanon, Morocco, Palestine, and Yemen. ${ }^{5}$ I also included Tunisia, whose earliest survey is from 2011 (after the ousting of Ben Ali, before the Constituent Assembly elections), as its lasting democratic transition makes it a good reference point, against the Egyptian case, to check whether a transition's success or failure makes much of a difference.

\subsection{Political-Institutional Trust}

All surveys provide several specifications of the question "how much trust do you have in [institution]?" 6 Items on four institutions were selected to create the macrolevel index: parliament, government or prime minister, civil service, and media. Most surveys contain the first two, and by adding the latter two all selected surveys (see above) could be included. Factor analyses show that the four all tap one underlying dimension. ${ }^{7}$ As the different items' means were very similar (per country-year that is), the arithmetic mean of available items per respondent was calculated, rescaled to run from 0 to 1 , and aggregated per country-year. Several robustness checks using alternate operationalizations resulted in highly sim- ilar conclusions to the ones presented below. Where relevant, sensitivity tests and important deviations are discussed in the results section. The resulting indicator of societal-level political-institutional trust per countryyear has a real minimum of 0.26 (Lebanon 2011) and real maximum of 0.72 (Egypt 2011).

\subsection{Interpersonal Trust}

All surveys include only one dichotomous item, albeit a widely used one, to measure interpersonal trust: "most people can be trusted". ${ }^{8}$ Without further synchronization the 37 country-year scores could be calculated, ranging from 0.12 (Lebanon 2013) to 0.56 (Egypt 2011).

\subsection{Ethno-Religious Tolerance}

The variation in available items was greatest for tolerance as concept. Still, most surveys did include several items on objecting to people from certain societal groups as neighbors, and these have been applied to studies of tolerance before (e.g. Ciftci, 2010; Moaddel, 2006; Spierings, 2014). From the "neighbor items", I selected those that allowed for including as many surveys as possible, while at the same time representing a coherent concept of tolerance, in this case ethno-religious tolerance: neighbors from another religion, race, or country, people with a migration background, and people who speak a different language.

As the religion and race items are closest to the theoretical concept and present in most surveys (24), they are used as synchronization benchmark. Yet further synchronization is needed to create comparable aggregate scores, because the "popularity" of the societal groups and availability of items varies across country-years. This synchronization entails a correction of each nonbenchmark item by an item-unique synchronization factor, which is calculated by comparing scores on surveys that include both the benchmark items and the other item. ${ }^{9}$ Consequently, six more country-years could be included. For Egypt 2008 no neighbor item was present, but the same synchronization procedure could be applied to an alternative item theoretically linked to this concept of tolerance ${ }^{10}$ available in two other surveys that included the benchmark items. Additionally, the third AB

\footnotetext{
${ }^{3}$ The models and figures are not controlled for individual-level characteristics such as age and education. First of all, because the number of macro-level cases is relatively small in statistical terms. Secondly, because it is known that demographic changes only lead to slow and rather gradual changes. The "raw figures" in the graphs are actually more informative: they show what the trends in civic attitudes were per country before the uprisings. I take these trends explicitly into account when judging the changes after the uprisings.

${ }^{4}$ If available, post-stratification weights are applied.

${ }^{5}$ Bahrain and Sudan are excluded. The 2014 Bahrain sample included only seven of twelve regions, which makes it difficult to compare the two surveys and assess developments in attitudes in Bahrain. Between the two Sudan surveys South Sudan became independent, troubling the validity of a comparison.

${ }^{6}$ A great deal; quite a lot; not very much; none at all.

${ }^{7}$ PAF, oblimin, 20,330 respondents with scores on all four items; all factor loadings > 0.6, KMO 0.782, Bartlett's test significant.

8 Possible answers: (1) most can be; (0) can't be too careful.

${ }^{9}$ The exact procedure can be obtained from the author. Briefly: weighted means are calculated only on the cases with valid benchmark-and other-item scores. Each item has a conceptual minimum of 0 . The benchmark mean is divided by the other-item mean: the synchronization factor. Valid scores on the other item in all surveys are then multiplied by the synchronization factor. Consequently, the same group of respondents will have the same aggregate tolerance score regardless of whether one used the benchmark or the other item.

10 "How important should having ancestors from Egypt be as requirement for somebody seeking citizenship of Egypt?"
} 
round did not include neighbor items, but asked whether "In a Muslim country, non-Muslims should enjoy less political rights than Muslims."11 For five of the countryyears of those surveys, WVS surveys are available that do include benchmark items. In this case, the synchronization factor was calculated by comparing the WVS benchmark means with the $A B$ political-rights means on exactly the same country-years. ${ }^{12}$ This enabled five more country-years to be included in the analyses below.

Based on the synchronized items, the final societaltolerance scores ${ }^{13}$ are calculated by taking the arithmetic mean of all available items per respondent aggregated per country-year (real minimum: 0.47 [Yemen 2013]; real maximum: 0.92 [Lebanon 2011]). These figures can be interpreted as proxies for the proportion of people that do not object to people of another religion or race as neighbors (the benchmark). Several alternative ethnoreligious tolerance operationalizations (covering fewer country-years) are used to test the sensitivity of the below conclusions to the followed procedure, which will be discussed in the respective analysis sections. The presented general conclusions are robust.

\section{Empirical Analysis}

\subsection{Arab Uprisings}

The expectations formulated in the theory section are partly conditional on whether major protests took place, whether these were organized along ethno-religious lines, and whether they resulted in democratic reform and regime change. The nine countries studied here are therefore classified accordingly. Table 1 summarizes this and makes the expectations formulated above more tangible. For instance, the theoretical expectation on interpersonal trust declining (Expectation 4) now implies that such decline in trust should be found in Iraq, Lebanon, and Yemen particularly (see Table 1) for the expectation to hold.
Turning to these conditioning factors, I firstly distinguish between countries where major protests took place in 2010-2011 and where they did not, whereby I build on Brownlee, Masoud and Reynolds (2013) by defining "major protests" as large crowds protesting over multiple days and protests spreading across the country. ${ }^{14}$ Secondly, among the countries that saw such protests, I can distinguish three where the protests were strongly linked to ethno-religious differences: Iraq, Lebanon, and Yemen. In Iraq, major protests revolved around the issue of the Sunni militia Sons of Iraq, who felt mistreated by the Shi'a-dominated government ( $\mathrm{Al}$ Jazeera, 2008; Dermer, 2014; The Daily Star, 2013); in Lebanon, protests were driven by Sunnis protesting the Shi'a-backed candidate nominated for Prime Minister (e.g. Al Jazeera, 2011; Lutz, 2011); and in Yemen ethnoreligious separatist protests-major parties being Northern Houthis and Southern Islamist secessionists-quickly led to violent conflict that saw political assassination attempts and protesters being fired upon (see BBC, 2016; Kasinof, 2016; Longley Alley, 2013, 2015).

Thirdly, as for the aftermath, institutional changes are at the core of the expectations formulated above. ${ }^{15}$ Again building on Brownlee et al. (2013), I distinguish between countries where regime change took place and those were it did not. In three of the nine, the full set of institutional rules was replaced, leading to a fundamentally different type of political system, but, as Table 1 indicates, the outcomes are quite different. In both Egypt and Tunisia a democratic transition took place, but in Egypt this did not last, with the Qandil governments and president Morsi rolling back the democratic transition and the military aborting it completely (Brown, 2013); whereas in Tunisia the Islamist Ennahda and the other major parties more or less accepted the new rules (Netterstrøm, 2015). In Yemen, the regime collapsed and a still ongoing civil war broke out. Among the countries without regime change, a distinction can be made between countries that did introduce some reforms and

Table 1. Protest and political change in nine MENA countries.

\begin{tabular}{llll}
\hline & No major protest & $\begin{array}{l}\text { Protest driven by particular } \\
\text { religious or ethnic groups }\end{array}$ & Broad, peaceful protest \\
\hline No substantive change & $\begin{array}{l}\text { Algeria } \\
\text { Palestine }\end{array}$ & $\begin{array}{l}\text { Iraq } \\
\text { Lebanon }\end{array}$ & Morocco \\
$\begin{array}{l}\text { Minor democratic reform } \\
\text { Unsuccessful democratization }\end{array}$ & Jordan & & Egypt \\
$\begin{array}{l}\text { Successful democratization } \\
\text { State breakdown }\end{array}$ & & Yemen & Tunisia \\
\hline
\end{tabular}

\footnotetext{
11 Possible answers: strongly agree, agree, disagree, strongly disagree.

12 The exact procedures can be obtained from the author. Only Muslim respondents are included, and weights assured similar survey sizes for AB and WVS per country-year.

13 Palestine 2006 included no suitable data.

14 The differences with Brownlee and colleagues' classification are caused by my exclusion of their criterion that the protesters occupied public places, which is less relevant to this study's central question.

15 Opposed to, for instance, financial appeasement or firing state officials.
} 
those where this was not the case. Though the leaders of most of these countries did not see fit to announce and implement political-institutional reforms, in Jordan more freedom of expression was allowed and in Morocco some of the king's powers have been transferred to elected politicians (Dalacoura, 2012).

\subsection{Political-Institutional Trust}

To start with the developments before the uprisings, Figure 1 shows a distinct downward trend in politicalinstitutional trust across the region, with only three exceptions. ${ }^{16}$ Remarkably, the latter are all found around 2006-2007. This sudden increase might relate to the 2006 Lebanon war, which in the Arab MENA is general perceived to have been won by Hezbollah, defeating Israel (e.g. El-Husseini, 2015). Governments also claimed this victory, with Syrian president Assad, for instance, identifying himself with a growing Arab resistance against Israel (Al-Assad, 2006). It is not unlikely that a rally-around-the-flag mechanism might have been at play here, with the public feeling positive about the Arab leaders' performance. ${ }^{17}$ Evidently, this explanation deserves more research (e.g. why does Algeria deviate from the pattern? $)^{18}$ but that is beyond the scope of this study. The main observation here is a long-term downward trend in political-institutional trust, which seems to have fed the uprisings.

Ignoring the existing trend discussed above could lead to overestimating the impact of the uprisings. For instance, the decline in Palestine is hardly a trend break, and the declines in Jordan and Morocco are more modest than one might have concluded simply comparing the 2011 and 2013-2014 figures. More generally, Iraq and Lebanon show no clear increases or decreases. Trendbreaking drops were found in Egypt, Jordan, Morocco, Tunisia, and Yemen - the five countries that saw regime change or some democratic reform (see Table 1). It is worth zooming in on this connection.

The drops in political-institutional trust are strongest in the three regime-change countries. Egypt and Tunisia saw a democratic transition and had relatively high trust levels just after the uprisings. For instance, in 2011, after Mubarak's ousting and Egypt's first democratic elections, trust was considerably higher than in 2008, the year of the previous survey. However, neither in Egypt nor in Tunisia did the high trust turn out to be durable. The undemocratic behavior in Egypt can partly explain the major drop in trust, but in Tunisia, with its rather stable democratization, trust likewise dropped. Considering the socio-economic problems at the core of the uprisings, it seems important that both governments did not solve these issues overnight. The remaining socioeconomic problems can explain the nullification of the democratization trust boost. Also, the results for Jordan and Morocco further support this reasoning. Both countries saw minor democratic reforms, and though the decline in trust seemed to be slightly weakened at first, trust declined more strongly again some years after the reforms. Finally, in Yemen a minor increase in

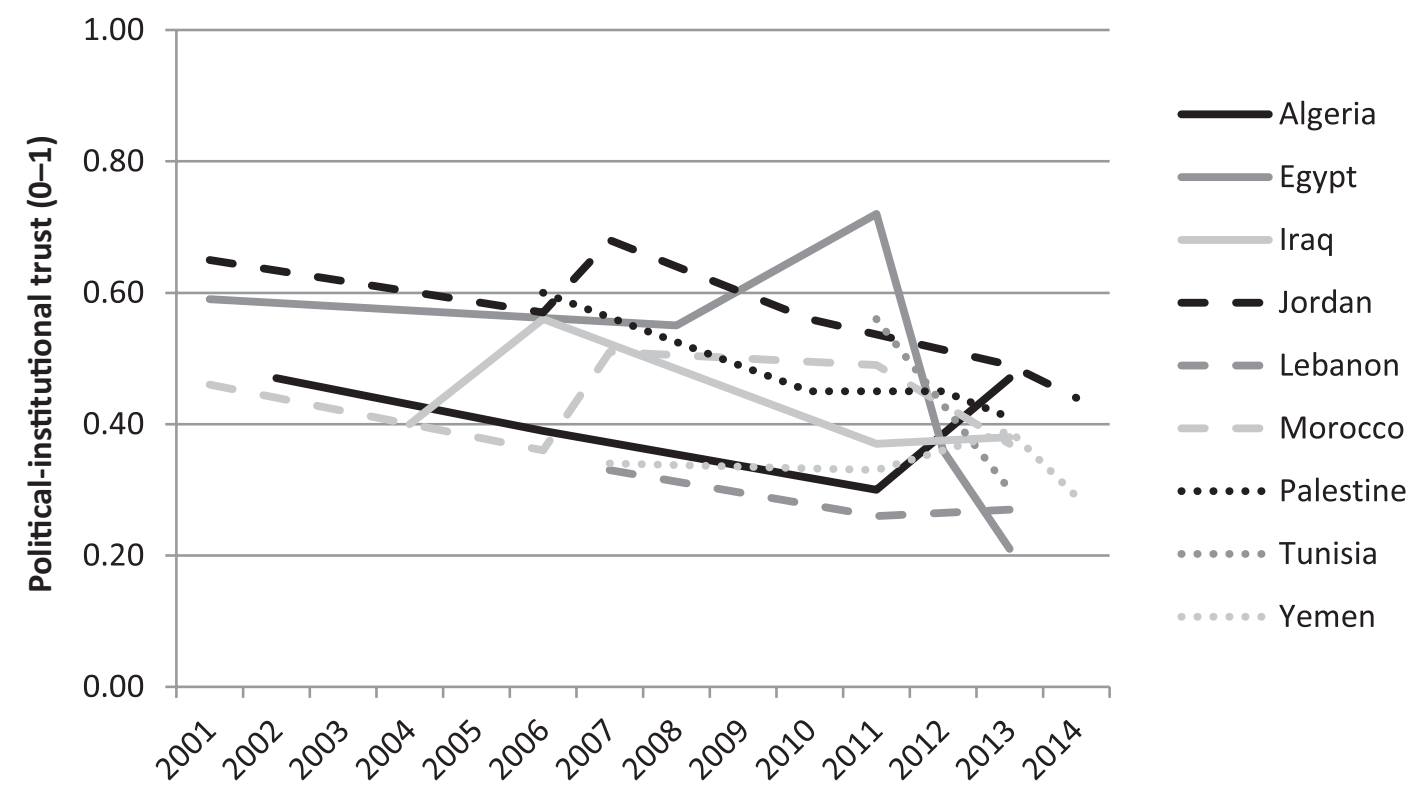

Figure 1. Political-institutional trust in nine MENA countries (2001-2014).

\footnotetext{
16 Based on all the consecutive surveys between 2001 and 2011, with the exception of Egypt, for which the 2011 survey was not included as this was conducted after the fall of Mubarak and the parliamentary elections.

${ }^{17}$ Further support comes from Israel's main antagonist Palestine having the highest trust score in 2006. Methodological explanations are less convincing: country-years with both a WVS and AB survey do not show a consistently higher score on the WVS data, from which the 2006-2007 data stem; item-difference is unlikely to have caused the pattern, as similar effects are found for parliament scores only.

18 The Egypt 2008 deviation is explained by being the only survey without items on either parliament or the executive branch.
} 
trust was seen in the first survey after Saleh handed over power and signed the transition plan in 2012. However, the later complete breakdown of the country and the outbreak of civil war made political trust drop to a low. It seems that initial reforms had positive effects in all five countries, but as people's (socio-economic) problems were not resolved their daily experiences did not change. Consequently the uprisings ultimately harmed political trust as people became disappointed in the performance of their (new) governments and institutional elites.

Algeria seems to be a major exception to this mechanism, with trust strongly increasing between 2011 and 2013, though no institutional reform was introduced (see Table 1). A closer look, however, suggests that the 2012 parliamentary elections might have had the same effect as reforms in other countries. Even though no substantial institutional changes accompanied them, they were internationally considered to be relatively democratic (Al Arabiya, 2012; Al Jazeera, 2012). This explanation fits the larger pattern discussed above, but for that to hold future studies with data from 2014 onwards should also show lower levels of trust, since Algeria's government has also not solved its larger social problems, which include corruption and unemployment (Cheref, 2016; World Bank, 2016).

Overall, a general negative trend in political trust before the uprisings was followed by a more differentiated impact of the uprisings, as is also confirmed by additional statistical models. ${ }^{19}$ In the conclusion, I will return to the theoretical expectations.

\subsection{Interpersonal Trust}

Before the uprisings, a trend of decline is found for interpersonal trust, albeit a somewhat weaker one than for political trust. Moreover, the publics of Morocco and Yemen show rather stable levels of interpersonal trust, and some increases are even found as well. Still, a pooled overall regression model on the surveys from before the uprisings shows a statistically significant negative trend. ${ }^{20}$

Turning to the uprisings, initially high levels of interpersonal trust or considerable increases are found just after the uprisings in Algeria, Egypt, Iraq, and arguably Palestine. Marked declines, partly following these increases, were found for Egypt, Jordan, and Tunisia. This cluster of three is hard to fit with the distinctions presented in Table 1, given that in the two other countries that saw reform or institutional change, Morocco and Yemen, interpersonal trust was rather stable. As such, a declining interpersonal trust cannot be linked to, for instance, the uprising being organized along religious lines. The only pattern that seems to appear is that decreases in social trust are found after a few years in countries that have seen a democratic transition, but where social and economic problems remain strong (Egypt, Tunisia), as will be elaborated on in the conclusion.

\subsection{Ethno-Religious Tolerance}

For tolerance, the overall pattern is certainly not one of decline; rather stable at first, it seems to be increas-

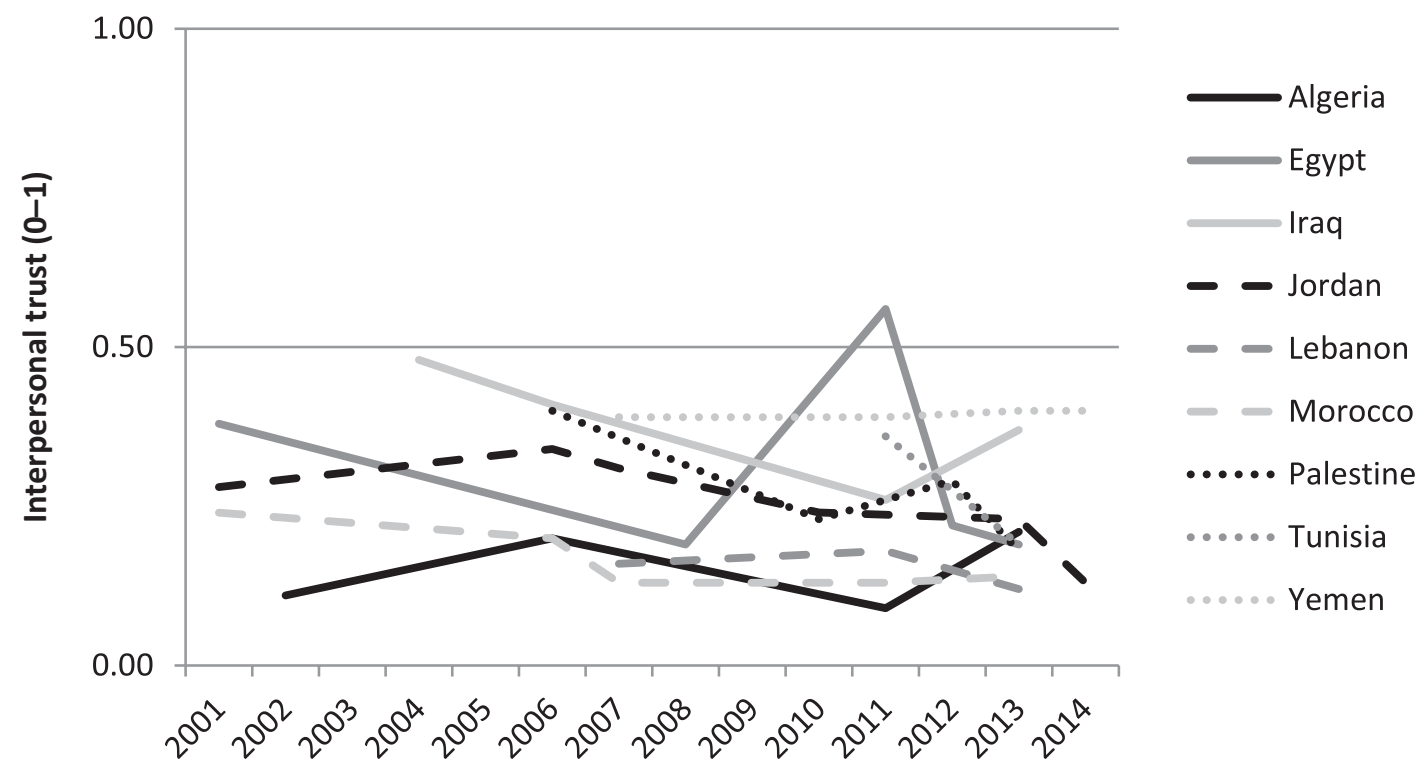

Figure 2. Interpersonal or social trust in 9 MENA countries (2001-2014).

\footnotetext{
${ }^{19}$ A two-level regression model with respondents embedded in countries shows a negative and significant impact of "years since 2001 "; a dummy measuring the impact of the uprisings shows no overall negative and significant effect, but including it in the model's random part shows the uprisings' effect to differ significantly between countries.

${ }^{20}$ Respondents embedded in country-years in countries, with random intercepts and "years since 2001" as core explanatory factor.
} 
ing towards 2010 and 2011, indicating some kind of public unification just before the uprisings. The 2007 dips in Jordan and Morocco are exceptions that mirror the increased political trust there (cf. Figures 1 and 3). The increased saliency of the Arab-Israeli conflict due to the Lebanon war might have simultaneously decreased ethno-religious tolerance, as under those circumstances more people have had Jewish people in mind when they were asked about neighbors with another religion. Additional analyses provide further support for the idea that it was particularly the tolerance towards Jewish people that decreased during those years. ${ }^{21}$

The developments following the uprisings are strikingly uniform: in all nine countries we see a decline between 2010-2011 and 2012-2013. Across the MENA, tolerance towards people of other ethno-religious background seems to have decayed in the first years after the uprisings-though it should be noted that in Egypt, Jordan, and Yemen it has been rising again since 2012 or 2013. One might seek an explanation for this region-wide decline in the different survey item included in the third $A B$ round, but a similar pattern is also found when only including the item on neighbors from a different religion or only including the different years of one survey type (WVS or $A B$ ).

Regarding the most recent increases, we should cautious interpreting these, partly because 2014 data are only present for two countries. It thus cannot be said whether this is a region-wide effect or a more countryspecific one. The core finding for now is that across the region the short-term effect of the uprisings and their aftermath is one of decreasing ethno-religious tolerance.

\section{Conclusions}

After the Arab uprisings rocked the MENA region more than five years ago, a great deal has been said about the uprisings' impact, including their impact on the civic attitudes of the people, of whom so many took to the streets from late 2010 onwards. At the same time, a systematic account of how civic attitudes such as trust and tolerance have developed across the region has so far remained lacking. In this study, I set out to shed more light on this issue by both comparing civic attitudes in the Arab MENA after the uprising with the trends before the uprisings and comparing these developments among MENA countries.

The analyses did not show the region-wide drop in political-institutional trust that was suggested in some MENA-country case studies. As Robbins noted, the differences in transitions and outcomes need to be understood to explain the effects on public opinion (Robbins, 2015, p. 87). However, the results do not resemble a picture of immediate decreasing trust in democratic transition countries (Expectation 2), as was expected based on the CEE literature (e.g. Growiec \& Growiec, 2014; Murray, 2008). It was in countries that have seen major or minor institutional democratic reformsor that moved towards democracy through relatively democratic elections-where political trust at first increased. However, the countries where democratization took place also then showed a declining political trust later on, in some case rather severely. As Longley Alley (2013) observed for Yemen, a likely cause for this is that, despite the institutional changes, the economic ills remained, harming the newfound trust in said political institutions. This initial increase and later decline supports Expectation 3, as well as the CEE literature's observation that it is people's experiences that count, not the actual transition (see Guérin, Petry, \& Crête, 2004).

People's general trust in the world around them did not show a region-wide response to the uprisings either, nor was this interpersonal trust mainly harmed in countries where ethno-religious differences were at the root

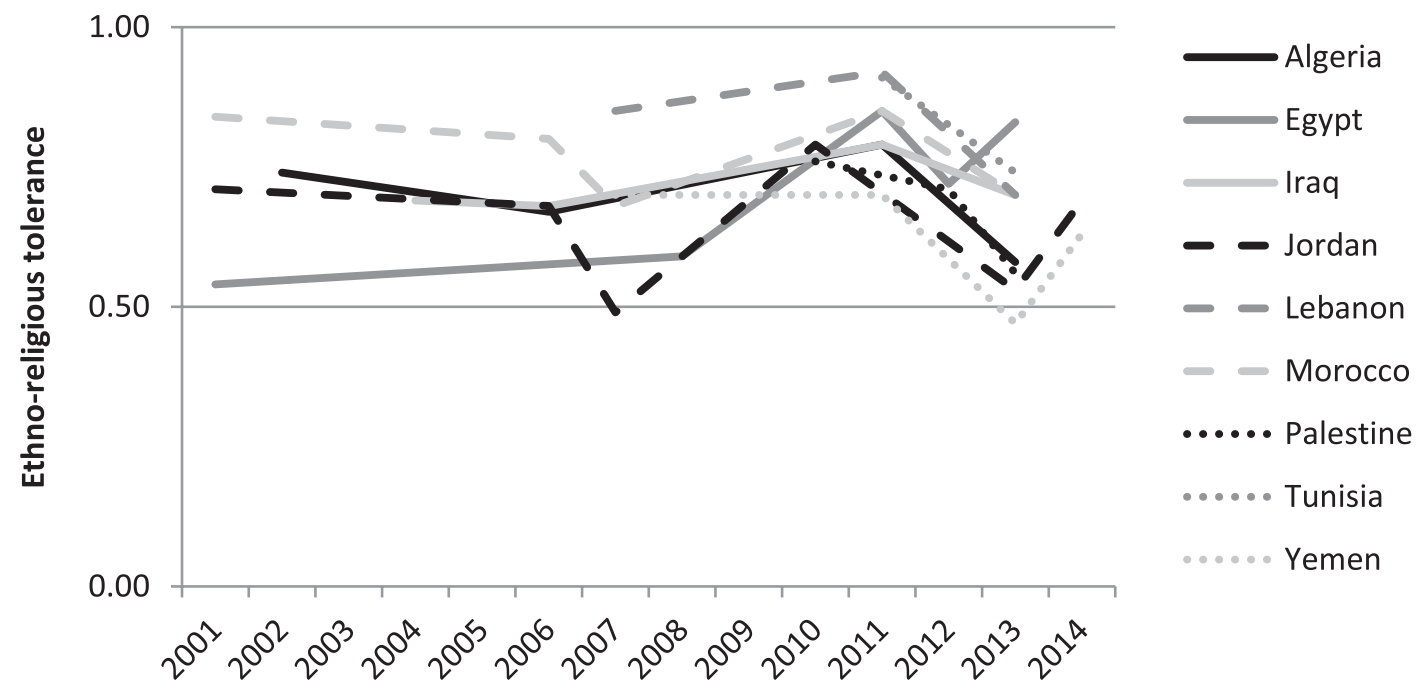

Figure 3. Ethno-religious tolerance in nine MENA countries (2001-2014).

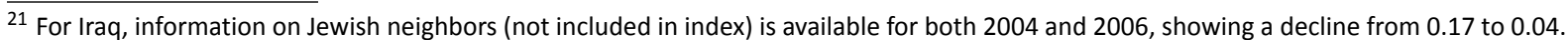


of the uprisings. This undermines Expectations 4 and 5. The result did, however, support Newton's (2001) more general claim that the two types of trust correlate at the societal level, as the reforms' impact on societal trust seem to be a reflection of their influence on politicalinstitutional trust. This is in line with Expectation 6, noting that for this "negative spillover effect" from political to general trust to occur, the political reforms underlying the disappointment must be major and the new leaders-not hailing from the ruling elites-must take office first. Under those circumstances, the impact of political events on people's trust in the system and in politicians seems to rub off on the more general interpersonal trust, as was the case in Egypt and Tunisia. This conclusion seems to go against those in the CEE literature, which more often discusses interpersonal trust as fertile soil for political trust (Lühiste, 2006) or argues that people compensate for a lack of political trust with trust in informal networks (Marinova, 2011). The MENA analyses here suggest a new mechanism heretofore unexplored in the literature: if new leaders not previously part of the authoritarian ruling elite take over, changes in political trust can spill over into more general trust, as these new leaders in a way also represent the ordinary people or "common man". This pattern seems to be rather relevant for Western societies too where "outsider" populist leaders might become part of the governing elite, but probably will not solve all supposed problems overnight (cf. Rooduijn, 2013).

A decline in ethno-religious tolerance was found across the MENA (Expectation 8), not just in countries where ethno-religious violence or conflict broke out during or following the uprisings (Expectation 7). In that sense, the situation is more alarming than Heydemann's (2013, p. 65) warning about the events in Syria destroying intersectarian tolerance in areas affected by the conflict. Apparently, the general saliency of religious cleavages and cross-border ethnic or religious identification also facilitated a decrease in ethno-religious tolerance in countries without salient religious conflicts within their borders. It seems that in understanding the uprisings' impact on public opinion, transnational identities and discourses should not be underestimated as drivers of people's threat perceptions. To further test and understand these mechanisms, future in-depth interviews and survey case studies could focus on people's perception of religious tensions across the region and on their tolerance towards other ethno-religious groups, both in countries where these conflict were very prominent (e.g. Bahrain, Lebanon) as well as in countries where these tension are far less so (e.g. Algeria, Tunisia).

All in all, this study's results clearly support Expectation 1 that the impact of the uprising is not the same for each civic attitude as well as Robbins' (2015) claim that the impact of political shocks like the Arab uprisings are not unequivocal but conditional on the institutional context and specific events in the different countries. To understand what is going on in the MENA, it cannot be stressed enough that the MENA region is no homogenous bloc of authoritarian regimes.

At the same time, the patterns discussed above do indicate that general mechanisms are at work, though they translate differently depending on the context. Most clearly, people's experiences, particularly what they perceive to be threats and how they feel about the political elite's performance, are key in understanding the uprisings' impact on civic attitudes in the MENA. Though on the one hand this is in line with the larger literature, on the other there are particularities to the MENA that ensure results from studies on, for instance, CEE cannot be translated directly to transitioning countries in the MENA region. Most importantly, (1) the shared Arab identity and language in the MENA seems to allow threat perceptions to travel across borders; (2) under economic stress, as is the case in many MENA countries, the political performance of new leaders is not just measured by how these leaders deal with the new political order, but also whether they solve existing economic problems (quickly); and (3) if long-lasting authoritarian regimes transition towards democracy, not at the hand of the ruling elite, but through a takeover by people who did not belong to these elites before, the new leaders not only represent "politics", but also the general people, and their performance influences people's perception of both.

In conclusion, the uprisings might have partly stemmed from declining trust and increased tolerance, but above all they have considerably affected public trust and tolerance in the MENA, at least in the short term. Despite some initial positive effects, the larger patterns are all of decreasing trust and tolerance. The picture has thus turned rather grim, as the conflicts following the uprisings and the disappointment among the public seem to have done more harm than good when it comes to the civic attitudes that are fundamental to build stable democracies with accountable governance for and by the people. Still, some relief appears to be on the horizon: from 2013-2014 onwards, civic attitudes did recover in some countries. Future comparative surveys are needed to see whether the uprisings were just a ripple, whether these relatively stable civic attitudes will rise, return to their prior levels, or sink even further.

\section{Acknowledgements}

This study is based on a project funded by The Netherlands Organisation for Scientific Research, grant number 451-15-006.

\section{Conflict of Interests}

The author declares no conflict of interests.

\section{References}

Al Arabiya. (2012, May 13). U.S. hails Algerian election despite suspicions of fraud. Al Arabiya News. Re- 
trieved from https://english.alarabiya.net/articles/ 2012/05/13/213759.html

Al Jazeera. (2008, October 3). Baghdad to pay Sunni groups. Al Jazeera. Retrieved from http:// www.aljazeera.com/news/middleeast/2008/10/2008 10151630737451.html

Al Jazeera. (2011, January 25). Lebanon protests turn violent. Al Jazeera. http://www.aljazeera.com/news/ middleeast/2011/01/201112535328227823.html

Al Jazeera. (2012, May 4). Is Algeria immune to the 'Arab Spring'? Al Jazeera. Retrieved from http:// www.aljazeera.com/programmes/insidestory/2012/ 05/201251465357500445.html

Al-Assad, B. (2006, August 15). Speech at Journalists Union 4th Conference. Syrian National News Agency. Retrieved from https://web.archive.org/web/2012 0226221705/http://www.sana.sy/index_eng.html

Barr, J. (2011). A line in the sand: Britain, France and the struggle that shaped the Middle East (1st ed.). New York, NY: Simon and Schuster.

BBC. (2016, October 14). Yemen crisis: Who is fighting whom? BBC. Retrieved from http://www.bbc.com/ news/world-middle-east-29319423

Benson, M., \& Rochon, T. R. (2004). Interpersonal trust and the magnitude of protest. A micro and macro level approach. Comparative Political Studies, 37(4), 435-457.

Boduszyński, M. P., \& Pickard, D. (2013). Libya starts from scratch. Journal of Democracy, 24(4), 86-96.

Brown, N. J. (2013). Egypt's failed transition. Journal of Democracy, 24(4), 45-58.

Brownlee, J., Masoud, T., \& Reynolds, A. (2013). Why the modest harvest? Journal of Democracy, 24(4), 29-44.

Chanley, V. A. (2002). Trust in government in the aftermath of 9/11: Determinants and consequences. Political Psychology, 23(3), 469-483.

Cheref, A. (2016, March 7). In Algeria, corruption bedevils the economy. The National. Retrieved from http:// www.thenational.ae/opinion/comment/in-algeria-co ruption-bedevils-the-economy

Ciftci, S. (2010). Modernization, Islam, or social capital: What explains attitudes toward democracy in the Muslim world? Comparative Political Studies, 43(11), 1442-1470.

Dalacoura, K. (2012). The 2011 uprisings in the Arab Middle East: Political change and geopolitical implications. International Affairs, 88(1), 63-79.

Davis, D. W., \& Silver, B. D. (2004). Civil liberties vs. security: Public opinion in the context of the terrorist attacks on America. American Journal of Political Science, 48(1), 28-46.

Dermer, P. (2014, July 1). The 'Sons of Iraq', abandoned by their American allies. The Wall Street Journal. Retrieved from http://www.wsj.com/articles/philipdermer-the-sons-of-iraq-abandoned-by-their-ameri can-allies-1404253303

Djupe, P. A., \& Calfano, B. R. (2012). American Muslim investment in civil society political discussion, dis- agreement, and tolerance. Political Research Quarterly, 65(3), 516-528.

Easton, D. (1975). A re-assessment of the concept of political support. British Journal of Political Science, 5(4), 435-457.

El-Husseini, R. (2015, April 13). The Muslim world is turning on Hezbollah. The National Interest. Retrieved from http://nationalinterest.org/feature/themuslim-world-turning-hezbollah-12608

Fish, M. S. (2002). Islam and authoritarianism. World Politics, 55(1), 4-37.

Geddes, B. (2007). What causes democratization? In C. Boix \& S. Stokes (Eds.), The Oxford handbook of comparative politics (1st ed., pp. 317-339). Oxford: Oxford University Press.

Gibson, J. L. (2009). Political intolerance in the context of democratic theory. In R. E. Goodin (Ed.), The Oxford handbook of political science (1st ed., pp. 409-427). Oxford: Oxford University Press.

Gross, K., Aday, S., \& Brewer, P. R. (2004). A panel study of media effects on political and social trust after September 11, 2001. The Harvard International Journal of Press/Politics, 9(4), 49-73.

Growiec, K., \& Growiec, J. (2014). Trusting only whom you know, knowing only whom you trust: The joint impact of social capital and trust on happiness in CEE countries. Journal of Happiness Studies, 15(5), 1015-1040.

Guérin, D., Petry, F., \& Crête, J. (2004). Tolerance, protest and democratic transition: Survey evidence from 13 post-communist countries. European Journal of Political Research, 43(3), 371-395.

Heydemann, S. (2013). Syria and the future of authoritarianism. Journal of Democracy, 24(4), 59-73.

Hutchison, M., L. \& Gibler, D. M. (2007). Political tolerance and territorial threat: A cross-national study. Journal of Politics, 69(1), 128-142.

Inglehart, R. (1997). Modernization and postmodernization: Cultural, economic, and political change in 43 societies (1st ed.). Princeton, NJ: Princeton University Press.

Kaase, M. (1999). Interpersonal trust, political trust and non-institutionalised political participation in Western Europe. West European Politics, 22(3), 1-21.

Kasinof, L. (2016, October 18). Yemen isn't just a proxy war between Saudi Arabia and Iran. Slate. Retrieved from http://www.slate.com/articles/news _and_politics/foreigners/2016/10/the_yemen_confl ict_is_not_just_a_proxy_war.html

Longley Alley, A. (2013). Yemen changes everything....and nothing. Journal of Democracy, 24(4), 74-85.

Longley Alley, A. (2015. April 8). Nobody will win the war in Yemen. Al Jazeera. Retrieved from http://www. aljazeera.com/indepth/opinion/2015/04/win-war-ye men-150407082542371.html

Lühiste, K. (2006). Explaining trust in political institutions: Some illustrations from the Baltic states. Communist and Post-Communist Studies, 39(4), 475-496.

Lutz, M. (2011, March 20). Lebanon: Thousands rally against sectarian leaders. $L A$ Times. Retrieved from 
http://latimesblogs.latimes.com/babylonbeyond/20 11/03/lebanon-politics-women-middle-east-sectari an-.html

Marinova, D. (2011). When government fails us: Trust in post-socialist civil organizations. Democratization, 18(1), 160-183.

Mishler, W., \& Rose, R. (2001). What are the origins of political trust? Testing institutional and cultural theories in post-communist societies. Comparative Political Studies, 34(1), 30-62.

Moaddel, M. (2006). The Saudi public speaks: Religion, gender, and politics. International Journal of Middle East Studies, 38(1), 79-108.

Murray, C. (2008). Social capital and cooperation in Central and Eastern Europe: A framework for research on governance. Journal of Rural Cooperation, 36(1), 3-20.

Netterstrøm, K. L. (2015). The Islamists' compromise in Tunisia. Journal of Democracy, 26(4), 110-124.

Newton, K. (2001). Trust, social capital, civil society, and democracy. International Political Science Review, 22(2), 201-214.

Norris, P. (2011). Democratic deficit: Critical citizens revisited (1st ed.). Cambridge: Cambridge University Press.

Raiser, M., Rousso, A., \& Steves, F. (2004). Measuring trust in transition: Preliminary findings from 26 transition economies. In J. Kornai, B. Rothstein, \& S. Rose-Ackerman (Eds.), Creating social trust in postsocialist transition (pp. 55-70). New York, NY: Palgrave Macmillan.

Robbins, M. (2015). People still want democracy. Journal of Democracy, 26(4), 80-89.

Rooduijn, M. (2013). A populist zeitgeist? The impact of populism on parties, media and the public in Western Europe. Amsterdam: AISSR.
Rose, R., \& Mishler, W. (2011). Political trust and distrust in post-authoritarian contexts. In S. Zmerli \& M. Hooghe (Eds.), Political trust: Why context matters. (1st ed., pp. 117-140). Colchester: ECPR Press.

Scheepers, P., Gijsberts, M., \& Coenders, M. (2002). Ethnic exclusionism in European countries. Public opposition to civil rights for legal migrants as a response to perceived ethnic threat. European Sociological Review, 18(1), 17-34.

Skitka, L. J., Bauman, C. W., \& Mullen, E. (2004). Political tolerance and coming to psychological closure following the September 11, 2001, terrorist attacks: An integrative approach. Personality and Social Psychology Bulletin, 30(6), 743-756.

Spierings, N. (2014). The influence of Islamic orientations on democratic support and tolerance in five Arab countries. Politics and Religion, 7(4), 706-733.

The Daily Star. (2013, January 30). Iraq raises Sahwa militia pay to appease protesters. The Daily Star Lebanon. Retrieved from http://www.dailystar.com.lb/News/ Middle-East/2013/Jan-30/204244-iraq-raises-sahwa -militia-pay-to-appease-protester.ashx

Van der Meer, T., \& Dekker, P. (2011). Trustworthy states, trusting citizens? A multi-level study into objective and subjective determinants of political trust. In S. Zmerli \& M. Hooghe (Eds.), Political trust: Why context matters. (1st ed., pp. 95-116). Colchester: ECPR Press.

World Bank (2016, March 31). Algeria overview. The World Bank. Retrieved from http://www.world bank.org/en/country/algeria/overview

Zmerli, S., \& Hooghe, M. (Eds.). (2011). Political trust: Why context matters (1st ed.). Colchester: ECPR Press.

\section{About the Author}

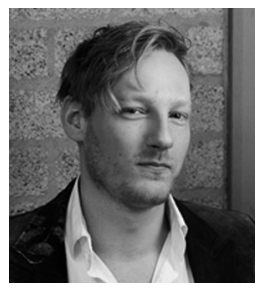

Niels Spierings is Assistant Professor in Sociology at Radboud University. Before, he has held positions at the London School of Economics and Political Science and the University of Essex. Recently, he obtained multiple grants for comparative studies of public opinion, democratization, gender equality and religion in the MENA region. His general interests include democratization, public opinion, Islam, gender, the MENA region, social media, migration, and populism. On these issues he has published monographs as well as in international journals. 